\title{
Pojmovna povijest, neoliberalizam i ljevica
}

\author{
TONČI KURSAR
}

Fakultet političkih znanosti, Sveučilište u Zagrebu

Todor Kuljić: Prognani pojmovi: neoliberalna pojmovna revizija misli o društvu, Clio, Beograd, 2018, 387 str.

\section{Uvod: pojmovi i njihova povijest}

Todor Kuljić, renomirani teorijski sociolog, knjigom Prognani pojmovi: neoliberalna pojmovna revizija misli o društvu poduhvatio se rijetko zahtjevne zadaće. Odlučio se, naime, intervenirati u "nepreglednosti velikog postsocijalističkog idejnog zaokreta" (Kuljić, 2018: 9). To je učinio kako bi ukazao da su upravo društvenoznanstveni pojmovi 'jezgra' svakoga političkog sukoba, jer se u njima uvijek "potiskuju stari i uvode se novi” (ibid.). U tom je smislu poduzeo istraživanje izvornog smisla nekoliko pojmova i pripadajućeg konteksta kao i njihova aktualnog značenja. Kuljić se pritom metodološki priklanja 'kritičkoj semantici' i tomu je prilagođen njegov istraživački program. Prva mu je zadaća propitati "aktualnu spoznajnu vrijednost prognanih pojmova" koji su tu sudbinu doživjeli u tzv. postdemokraciji, a nakon toga "sačuvati diferenciranu sliku prošlosti" tako što bi "objasnio povijesno doba ne samo današnjim aktualnim nego i prognanim pojmovima..." (ibid.: 39). ${ }^{1}$ U Prognanim pojmovima ne skriva se nadahnutost djelom Karla Marxa; autor čvrsto stoji uz "marksistički pristup obogaćen pojmovnom poviješću i primijenjen na tumačenje neoliberalne misli o društvu" (ibid.: 10). Takav je pristup, primjerice,

${ }^{1}$ U knjizi posebno mjesto ima pojam socijalne pravde kako bi se uočila "situacija jednog prognanog pojma iz koje nije izvučena dovoljna pouka” (2018: 39). Kuljić je čvrsto na stajalištu da je socijalna pravda "nemoguća i nerealna ako se promatra samo sa stajališta suženih mogućnosti koje nudi suvremeni kapitalizam” (ibid.: 10). 
prisutan kad on kaže da, iako neće zalaziti u "idejnu cjelinu pravdanja suvremenog kapitalizma", istraživanje "uvijek ima na umu strukturu cjeline u kojoj se iza pluralizma skriva nasilje" (ibid.: 16). I naposljetku, ako bi trebao birati između, primjerice, Reinharta Kosellecka² i Marxa, ${ }^{3}$ Kuljić bi uvijek izabrao potonjega.

Kuljić uvodno pokazuje mogućnosti pojmovne povijesti kao discipline "koja prati događanja i procese, ali zgusnute u idejne apstrakcije koje pomažu saznanju, ali imaju izvanspoznajnu moć" (ibid.: 64). Njegovo opredjeljenje za pojmovnu povijest proizlazi iz toga što ona ne daje opis, nego koristi 'opojmljivanje' kao "djelatnu komponentu i povijesnu signaturu hegemonijske svijesti svakog doba" (ibid.: 66). Posrijedi je dakle "unošenje smisla u događanja preko kategorija pojmova i diskursa... drukčije nego ono koje teče preko organizacije prošlosti oko događaja, ili oko procesa" (ibid.). ${ }^{4}$ Osim toga, pojmovna povijest istražuje "važne planske promjene društveno-znanstvenih i idejno-povijesnih termina, a ove su u pravilu povezane s promjenama svakodnevnog jezika" (ibid.: 29). Na taj je način moguće doprijeti do "središta političke i semantičke moći" (ibid.). Temeljno je načelo pojmovne povijesti da "nema vječnih istina... nego se istina uvijek iznova procjenjuje u svjetlu nove epohalne svijesti" (ibid.: 30). Uže metodološki gledano, ta je vrsta povijesti "zgusnuta u... ključnom pojmu koji povezuje širu mrežu srodnih pojmova..." (ibid.: 31). Stoga nas nipošto ne treba iznenaditi da se s vremenom "nosećim pojmovima mijenja opseg, sadržaj, a time ne samo spoznajni domet nego i izvanspoznajna uloga: npr. revolucija se iz astronomskog konteksta... pomiče u socijalni sklop" (ibid.). Ipak, pojmovima koji su 'dovoljno apstraktni' kao što su npr. demokracija i sloboda "promjena sadržaja ne bi narušila njihov kontinuitet" (ibid.: 17). Sve u svemu, kad su u pitanju pojmovi, posebnu ulogu gotovo uvijek imaju "'semantički stratezi' koji... [ih] zauzimaju, izvrću, mijenjaju im smisao, i okupiraju ih" tako da "istom pojmu različite grupe daju različito značenje" (ibid.: 80).

Kuljić operira dvama razdobljima kako bi uspostavio potrebnu temeljnu suprotnost, erom neoliberalizma i 'socijalnim 20. stoljećem'. To mu pomaže u na-

${ }^{2}$ Kuljić je veliku pozornost posvetio utemeljitelju škole pojmovne povijesti, njemačkom povjesničaru Reinhartu Kosellecku i njegovu stavu o pluralnosti povijesti. Općenito rečeno, Koselleck smatra da su pojmovi "kao zgusnuti izraz hegemonijskih teorija o društvu... izraz društvenih odnosa, sistemi tumačenja i kreatori smisla” (ibid.: 38). Vidi Koselleck, 2004, posebno 2. i 3. dio.

${ }^{3}$ Kad Koselleck iz svoje pluralističke perspektive kritizira Marxa zbog 'krutog monizma' njegova nauka, Kuljić, na osnovi Marxova pojma fetiša, ustvrđuje da je ovaj bio "stilist visokog ranga... s preciznim radom na pojmovima" (2018: 46).

${ }^{4}$ Kuljić, naravno, ne dvoji da je pojmovna povijest nadmoćna tzv. događajnoj povijesti (“duboka prosječnost događajne povijesti”). Po njemu, potonja pripada 'idejnom plebejstvu' "ne zato što je razumljiva širem krugu ljudi, nego zato što je njena politička uporaba providnija" (ibid.: 32). 
stojanju da odbaci navodnu realističnost neoliberalizma, odnosno da "dekonstruira maštovite priče koje zamagljuju realnost kapitalističkog nasilja" (ibid.: 96). ${ }^{5} \mathrm{Za}$ nimljivo je da Kuljić smatra kako je stvarnost u neoliberalnoj redakturi postavljena tako da nema alternativu, ali da je, prije svega, kontingentna. Kad kaže da je kontingentna, smatra da je stvarnost posljedica okolnosti, odnosno da ne ovisi o strukturnim čimbenicima/odnosima. Međutim, neoliberalizam nije potpuno prepušten 'kontingenciji', nego je "bliži relativističkoj represivnoj toleranciji"' (ibid.: 23). Tu vrstu tolerancije pomažu pojmovi, nastali od 1989., koji su "maska novog privida pluralizma" (koji podupire EU) (ibid.: 24). Zapravo danas prevladava ono što Kuljić naziva 'indeterminističkim pluralizmom' koji dokida "antagonističku viziju društva" (ibid.). Time su npr. socijalne nepravde osuđene na rješavanje logikom postojećega političkog poretka.

Što se tiče općih metodoloških odrednica, Kuljić želi biti razmjerno fleksibilan pa uglavnom malo toga apsolutizira. Kuljić tako smatra da "ni djelatnu ni spoznajnu moć pojmova ne treba precjenjivati" (ibid.: 44). Oni, neovisno o svojim mogućnostima, "ne mogu 'skenirati' stvarnost", odnosno stvarnost i njezine moguće varijante "ne mogu se uvijek pouzdano rekonstruirati iz prošlih pojmova koliko god ovi bili sistematski rekonstruirani..." (ibid.). No, unatoč izvjesnim deficitima, pojmovi imaju integrativnu funkciju u zajednici budući da "tek... borbeni pojam može integrirati i mobilizirati prostorno udaljene grupe koje se ne poznaju" (ibid.: 44-45).

Drugo, naglašava da, neovisno o materijalnim čimbenicima, "sam idejni preokret jest samostalna moćna poluga promjena i pravdanje realnosti” (ibid.: 25). To, međutim, odmah uravnotežuje tvrdeći da je, prije svega, na djelu "uzajamni povratni odnos baze i nadgradnje" (ibid.). Po njemu, i ne može biti drukčije jer kapitalizam ostaje "neupitni kanon koji definira gornju granicu tolerancije važnih pojmovnih debata" (ibid.). Iako je kao autor zaintrigiran spoznajnim dometima političkog diskursa, zapravo je skloniji "ideološko-kritički objašnjavati društveno-povijesnu uvjetovanost” (ibid.). I što je, po svemu, za njega još važnije, "trajnije grupne interese" (ibid.: 26).

Kako je Kuljić zainteresiran primarno za 'kritičku pojmovnu povijest', ne može ga se dojmiti samo spoznajna dimenzija pojma, nego uvijek i iznova inzistira na "signaturi novih klasnih odnosa" (ibid.: 68). Stoga ne čudi što je skeptičan prema pojmovima koji su nastali oko 1989. i stalno zaziva mogućnost da se iznova kori-

${ }^{5}$ U tom smislu sklon je i kritici diskurzivnih analiza budući da prije svega treba "razriješiti dilemu što je realni imperijalni kontekst kapitalizma: ekonomija ili pravo" (ibid.). Ako je ovo potonje, onda se radi o 'civiliziranju zaostalih', a ako je politička ekonomija, onda o njihovoj 'pljački i eksploataciji' (ibid.).

${ }^{6}$ Pojam 'represivne tolerancije' odnosi se na 'nepristranu' liberalnu toleranciju koja je za Herberta Marcusea nazadna jer štiti status quo. 
ste neki demobilizirani pojmovi (kapitalizam, prirodno pravo, socijalna revolucija, samoupravljanje). ${ }^{7}$ Ako sažmemo ono što Kuljić naglašava, razumljivo je da ne vidi osnovnu zadaću (knjige) tek kao pojmovnu rekonstrukciju. Prije je posrijedi pothvat koji, s "polazištem u kritici političke ekonomije i pojmovnoj povijesti", daje 'normativno-kritički osvrt' na naše doba (v. ibid.: 16). To se njegovo pretežito opredjeljenje, koje jasno prelazi granice pojmovne povijesti, može upotrijebiti kao osnova za vrednovanje njegove analize neoliberalizma i mogućnosti ljevice da ga prevlada. Kritičko čitanje bit će provedeno na osnovi nekih mislilaca na koje se sam Kuljić referira (Foucault, Rancière, Marcuse i Gramsci) kako bi se pokazalo da se nerijetko libi izvesti njihove ideje do krajnjih konzekvenci. Štoviše, iako piše s pozicije potrebe radikalne sistemske promjene, zanemaruje da je neoliberalizam kao hegemonija završio (s tzv. Velikom recesijom 2008.).

\section{Neoliberalizam}

Prva je istraživačka zadaća Prognanih pojmova definiranje neoliberalizma. Mjestimice ga Kuljić naziva i globaliziranim kapitalizmom. Gotovo u cijeloj knjizi na različite načine izvodi raščlambu tog fenomena koji je došao kao, recimo to tako, kontrarevolucionarni udar "nakon sloma evropskog socijalizma" (ibid.: 92). Osnovna mu je premisa da je posrijedi ne posebno revolucionaran sustav: "zaokret iz 1989. nije uveo nove, nego je samo obnovio stare vrijednosti: kapitalizam, nacionalizam i religiju" (ibid.: 113). Kuljić ipak želi preciznije odrediti što je posrijedi kod neoliberalizma i čini to tako što ga, najprije, karakterizira kao 'financijski kapitalizam' (ibid.: 101-102). Smatra da je to specifična vrsta kapitalizma koja prednost daje (zaoštreno kazano) novčanim špekulacijama u odnosu na proizvodnju dobara. ${ }^{8}$ Osim toga, značajnu ulogu u njegovu ostvarivanju pridaje digitalizaciji koja ubrzava financijske transakcije pa posljedično "dolazi do desinhronizacije politike i ekonomije" (ibid.: 104). Neizbježna je posljedica toga kontroverzna 'silikonska demokracija' u kojoj vlada 'represivna tolerancija': 'Internet je prije prepreka koja štiti sistem, osamljuje pojedinca koji sjedi pred računalom..., a sirotinja jest offline i onda kad je online" (ibid.: 109; 111).

\footnotetext{
${ }^{7}$ Autor se bavi i metaforom u političko-diskurzivnom prostoru. Za metaforu kaže da je "potrebna jer ima više stvari nego što ima pojmova za njih, pa je složenost realnosti nadmoćna nad sredstvima njenog reduciranja" (ibid.: 74). Dakle ona nastaje kad postoji semantički odnosno politički deficit. Laclau, primjerice, to izražava stilskom figurom katahreze pokazujući da je "politička konstrukcija naroda u osnovi katahrezijska" (Laclau, 2005: 71-72).

${ }^{8}$ U neoliberalizmu, dakako, postoji i drugo 'bojno polje'. Potisnuti su klasni sukobi, ali se zato u neoliberalnoj praksi sukobljavaju nacije: "razbijaju [se] ćirilične table u Vukovaru, a Bruxellesu i Berlinu je cilj dovesti ‘lijene Grke’ pameti” (2018: 103).
} 
Potom Kuljić tvrdi da postoji čvrsta veza liberalizma i neoliberalizma. Neoliberalizam je "najrazvijeniji kapitalizam, pouzdana osnova za razumijevanje prirode kapitalizma uopće" (ibid.: 94). ${ }^{9}$ Kako smo već naznačili, ne pridaje mu previše izvornosti pa naglašava da s klasičnim liberalizmom dijeli "dugu liniju skrivanja nasilja iza pluralizma" koje je "kostimirano raznim manipulacijama i pojmovima" (ibid.). Nasuprot Marxovoj kritici nasilja kapitalizma, liberalna je misao generalno "usavršavala skrivanje ekonomskog nasilja" (ibid.: 95). To ilustrira prvobitnom akumulacijom kapitala i ropstvom, što mu daje osnovu za tvrdnju da je "nasilje bilo logika ekspanzije kapitalizma, a ne incident" (ibid.: 94). ${ }^{10}$ Zajedničko liberalizmu i neoliberalizmu pronalazi tako u 'represivnom podvlašćivanju' i to je bit kapitalističke proizvodnje neovisno o njezinim formatima (ibid.: 97). I na kraju, po njemu, "osnovni je diskurs ideologa neoliberalizma antietatistički..." (ibid.: 112). Koliko to sve stoji i na koji način, trebali bismo vidjeti u izvodu koji slijedi.

Pokazani elementi nisu nevažni za raspravu o neoliberalizmu (u smislu njegovih ključnih pojavnosti i načina održavanja kapitalizma). Ipak, dojam je da ostaje potreba da vidimo što je neoliberalizam u svojoj biti. U Prognanim pojmovima Michel Foucault nije dobio previše prostora pa ćemo (kratko) izvesti njegovo viđenje neoliberalizma. U Rođenju biopolitike Foucault postavlja pitanje 'što je dakle neoliberalizam?' (Foucault, 2016: 138). Put ga vodi do pitanja koje postavljaju neoliberali (barem oni po njegovu odabiru): "kako možemo urediti sveukupnu primjenu političke moći na načelima tržišne ekonomije" (ibid.: 139). Odgovor ide ovim redom. Prije svega, Foucault tvrdi da neoliberali razmišljaju potpuno drukčije od liberala, što početno pokazuje analizom ideja tzv. 'ordoliberala' iz razdoblja prije, tijekom i nakon Drugoga svjetskog rata. Preokret je započeo ovakvim stavom: "I umjesto da kažemo: kad postoji jedna relativno slobodna tržišna ekonomija, na koji način državu treba ograničiti kako bi njezini učinci izazvali najmanju moguću štetu? - treba razmišljati na posve drukčiji način. Treba reći da ništa ne dokazuje da tržišna ekonomija ima mane, da ima kakav intrinzični nedostatak, budući da sve što joj pripisuju kao manu i kao posljedicu njezine neispravnosti treba pripisati državi" (ibid.: 123). Kako bi se zbila stvarna promjena, neoliberali kažu: "zahtijevamo od tržišne ekonomije mnogo više od onoga što se od nje zahtijevalo u 18. stoljeću" (ibid.). Foucault skicira i ono što je nekad funkcioniralo kao liberalno viđenje ogra-

9 Ovdje se uzda u Marxovu tvrdnju da je ‘čovjek ključ za anatomiju majmuna’ iz Osnova kritike političke ekonomije (v. Uvod); v. ibid.: 94.

10 Ovdje se poziva na Marxa i Incea; v. ibid.: 94. Kuljić je osobito kritičan prema neoliberalnim intelektualcima koji "pravdaju globalizacijski neokolonijalizam širenjem vladavine prava" (ibid.: 95). Pritom upozorava da se redovito zaboravljaju povijesne okolnosti u kojem su liberalni mislioci promicali slobodnu trgovinu i privatno vlasništvo. To ga navodi na zaključak da je tu uvijek riječ o pukim "ideološkim kategorijalnim normama” (ibid.). 
ničenja posezanja države: "Od ove granice, kad će biti riječ o ovome pitanju, i od ruba ovog područja, onda više nećeš intervenirati” (ibid.: 124). Budući da je država glavni krivac kao "nositelj intrinzičnih nedostataka", neoliberali od tržišne ekonomije traže nešto drugo: "Da bude sama po sebi, ne načelo ograničavanja države, nego načelo interne regulacije države" (ibid.).

Tu vidimo odbacivanje 'početne formule liberalizma', one o državi koja bdije nad ekonomijom. Ispada onda da "aktualni neoliberalizam nije nipošto... preporod, povratak starih oblika liberalne ekonomije formuliranih u 18. i 19. stoljeću” (ibid.). Sljedeće je pitanje može li tržište "doista imati moć formalizacije i za državu i za društvo?". Odgovor koji nalazimo u Foucaultovoj analizi glasi: “Da, tržišna ekonomija može uistinu i formirati državu i reformirati društvo, ili reformirati državu i formirati društvo" (ibid.: 125). Kako bi se to postiglo, treba, međutim, krenuti od temelja. Prvi je osporiti status razmjene koja je bila ključna za shvaćanje tržište u liberalizmu 18. stoljeća. Riječ je o odnosu "dvaju partnera koji razmjenom uspostavljaju ekvivalenciju između dviju vrijednosti” (ibid.). Od države se tražio nadzor, odnosno da "učini sve kako bi se poštivala sloboda onih koji razmjenjuju robu" (ibid.). Ukratko, zaključuje Foucault, "tržište je, na neki način, moralo biti jasno i slobodno mjesto" (ibid.: 126). Nasuprot tomu, neoliberalizam je ustanovio da "bit tržišta nije u razmjeni", nego "u konkurenciji”, što isključuje ekvivalenciju (kao u odnosu razmjene) u korist "nejednakosti" (ibid.).

Ordoliberali, kako se pokazuje, slijede ideju po kojoj samo konkurencija odražava punu logiku ekonomske sfere: "formiranjem cijena koje, budući da postoji... posvemašnja konkurencija, mogu mjeriti ekonomska dostignuća i stoga upravljati odabirom" (ibid.). ${ }^{11}$ Zanimljivo je da oni naglašavaju da se iz načela konkurencije ne može izvesti laissez-faire strategija, jer tržište nije "nešto što se stvara spontano i što bi država trebala poštivati upravo zato što je prirodna datost" (ibid.: 127). Uvijek stoga treba imati na umu da je konkurencija ponajprije 'načelo formalizacije': "pojaviti i stvoriti... [će se] isključivo pod stanovitim brižno i umjetno stvorenim uvjetima" (ibid.). Time se nadolazi do ključa ove priče, a to je da se konkurencija "može pojaviti... ako ju stvori aktivno upravljanje" (ibid.: 128). Odgovor na Foucaultovo pitanje s početku ovog izvoda bio bi da u neoliberalizmu više nije riječ o prostoru (ekonomije) koji treba potporu slobodi, nego da se "formalna načela tržišne ekonomije prenesu, odnose i projiciraju na opće umijeće upravljanja" (ibid.: 140). ${ }^{12}$

11 Usput, na 257. str. Kuljić je možda najbliže ovom određenju neoliberalizma: “nadmetanje u profitabilnosti jest vrijednost kojoj se svi klanjaju, svatko konkurira svakom... To je sacra scriptura (Sveto pismo) neoliberalizma".

12 V. o tome instruktivno u Noys, 2010. 
Sad kad smo pokazali ideju neoliberalizma (barem prema mjerodavnom Foucaultu) i ono što ide s njom (pitanje liberalizma, (anti)etatizma, konkurencije, razmjene i laissez-fairea), možemo nastaviti sa strukturom i dosegom same doktrine. Kuljić ne dvoji da neoliberalizam nije uspio samo zahvaljujući restrukturiranju postojećih pojmova, nego i zato što je "nametnuo druge pojmove: globalizacija, europeizacija, tranzicija, transformacija..." (2018: 19). ${ }^{13}$ Zbila se dakle 'restaurativna revolucija' koja je donijela "nove pojmove, ali ispunjene starim vrijednostima" (ibid.: 21). Kako god se prema njemu odnosili, novonastali diskurs donio je dramatične promjene koje su s vremenom samo akcelerirale: "nije donio samo novu sliku prošlosti nego i nova oruđa za tumačenje tektonskih lomova, novu socijalnu semantiku..." (ibid.). ${ }^{14}$

Kad je riječ o neoliberalizmu kao tekućoj doktrini, Kuljić ju vidi primarno kao 'nadklasni diskurs' koji "nije... nikakva nova i izvorna ideologija, nego samo zbog nadmoći, ogoljena buržoaska ideologija koja otvoreno i bez zamagljivanja... ističe vlastite ekonomske ciljeve" (ibid.: 133). Neoliberalizam je dakle vrlo izravna i sadržajno oskudna naracija pa ispada da mu je "dovoljno... pravdanje golom praksom" (ibid.: 262). ${ }^{15}$ Kuljić ovdje isprva odvaja praksu i ideologiju, ali onda kaže da je ta 'gola praksa' ujedno i ideologija ('vjera'). Priklonio bih se ovoj drugoj Kuljićevoj tvrdnji. Naime, svaka je praksa po sebi ideološka, a kapitalizam je, recimo to tako, prvak te discipline. Na to nas napućuju različiti autori, primjerice Marcuse, koji govori o "apsorbiranju ideologije u realitet” (Marcuse, 1989: 29), ili Žižek, koji tu vidi poseban oblik 'ideologije' kao "varljive mreže kvazispontanih pretpostavki i stavova koji tvore nesvodivi moment 'neideoloških' (ekonomskih, pravnih, političkih, seksualnih...) praksi” (Žižek, 1994: 15). I naposljetku, Rancière pokazuje da u 'duhu vremena' od 1989. (demokratska) politika može biti isključivo "izraz izvjesnog stanja onog društvenog, a razvoj proizvodnih snaga čini supstancijalni sadržaj tih formi” (Rancière, 2015: 90). U takvoj 'praksi' Kuljić vidi da 'demokratska hegemonija' omogućuje, primjerice, nevladinim udrugama da, prvo, svojom semantikom budu spona "između jezgre kapitalizma i njegove idejne mreže na periferiji" (2018: 86). I drugo, te udruge s "drugim unajmljenim uslužnim dijelovima intelektualne radne snage... kapilarno šire vrijednosti kapitalizma... (ibid.: 85). I na sve se

13 Time su, po Kuljiću, pojmovi poput slobode, jednakosti i bratstva postali anakronima.

14 Tu dimenziju Kuljić uočava u Francuskoj revoluciji i boljševičkoj revoluciji koja je kao 'hegemonijski diskurs' donijela "mrežu pojmova centriranih oko društveno-ekonomske nejednakosti i internacionalizma" (2018: 21).

${ }^{15} \mathrm{U}$ tim su okolnostima sve varijante lijeve ideologije/teorije marginalizirane, a marksizam je "sveden na akademsko štivo na sveučilištima" (ibid.). Usput rečeno, potonje je preoptimistična ocjena za npr. stanje na studiju politologije u Zagrebu, gdje se marksizam stidljivo vratio tek krajem dvijetisućitih, s razbuktavanjem globalne krize, nakon dvadesetak godina odsutnosti. 
to nadovezuju 'konfesionalno obojeni nacionalizmi' koje EU tolerira kao one koji su "saveznici kapitala protiv ljevice" (ibid.: 84).

Kako bi neoliberalizam mogao lakše funkcionirati, morao se posvetiti uklanjanju antagonizama. Budući da je nacionalizam, po Kuljićevu sudu, nastavio igrati aktivnu ulogu kao, recimo, pomoćna ideologija, najprije je stradala klasna solidarnost jer "narušava etničku homogenost čiji je konzervativni ideal da se nacija složi..." (ibid.: 117). S druge strane, neoliberalizam se nastavio na prethodne inačice liberalizma tako što (klasne) neprijatelje prevodi u 'protivnike', što umnogome utječe na mogućnosti sistemske promjene: "nema antagonističkih klasa nego klasno pomirljivih građana" koji se vode kao 'stanovništvo' (ibid.: 118). Tu se, međutim, Kuljić poziva na potencijal Rancièreove ideje o 'dijelu bez udjela' koja sugerira mogućnost "artikulacije unutarnje napetosti sistema" (ibid.). Kuljić je, u osnovi, na stajalištu marksizma budući da antagonizam, po njemu, "nije sukob različitih neekonomskih identiteta nego ekonomskih grupa" (ibid.). Poteškoća je u tome što Rancière nije marksist pa mu klasni sukob nema zadanu prednost u odnosu na ostale tipove političke borbe. To se može zaključiti iz Rancièreove knjige Na rubovima političkog (u tezi br. 5): "Narod koji je subjekt demokracije, dakle matični subjekt politike, nije skupina članova zajednice, tj. radnička klasa stanovništva" (Rancière, 2012: 179). Ukratko, takvo shvaćanje naroda nije vezano za postojeća sociologijska određenja: "Ne zauzima radnički puk, svjetina koja pati, teren političkog djelovanja, niti svoje ime poistovjećuje s imenom zajednice" (ibid.: 180). Narod je za Rancièrea ponajprije neočekivani subjekt, koji "omogućuje da se računica neuračunatih poistovjeti s čitavom zajednicom" (ibid.), što vidimo i u definiciji politike iz njegove Nesuglasnosti: "Politika postoji otkad postoji sfera pojavnosti subjekta zvanog narod, čija je vlastitost to da je različit od sebe samog" (Rancière, 2015: 83). ${ }^{16}$ Ukratko, Rancière je previše postmarksist za Kuljićev teorijski ukus.

Kad smo već kod Rancièrea, na osnovi njegove knjige Na rubovima političkog možemo razmotriti sudbinu (pojma) kapitalizma za koji Kuljić tvrdi da u našem stoljeću nema izravnog protivnika. Do globalne krize 2008. činilo se da je, uslijed navale sveprisutne tranzicije, pojam pao u zaborav. Neuporabu pojma Kuljić pripisuje, isprva, činjenici da je kapitalizam "dugo bio nepopularan u političkoj kulturi socijalističkih režima...” (2018: 273). I potom, da je ta riječ još posljednjih desetljeća prošlog stoljeća potisnuta jer je "prevladalo gledanje da nema alternative ovom poretku pa je i pojam suvišan" (ibid.: 79-80). ${ }^{17}$ Rancière ima drukčiji stav o potiskivanju pojma kapitalizma, koji se naslanja na neobične reperkusije Marxove metapolitičke kritike (buržoaske) države. Ako uvažimo da je metapolitika "tuma-

16 S tim u vezi demokracija u ovom viđenju promiče "prazan, dodatni dio, koji zajednicu odvaja od zbira dijelova društvenog tijela" (Rancière, 2012: 180).

${ }^{17}$ Kuljić se tu poziva na Razmiga Keseyana (knjiga Leva hemisfera, Beograd, 2016, str. 232). 
čenje politike s gledišta policije", onda svaka "iluzija, interval, pukotina" djeluju "kao znak neistine" (Rancière, 2012: 93). Slomom državnog socijalizma na djelu je (liberalna) metapolitika koja zaobilazi 'pukotinu' tako što se “čovjek i građanin miješaju u liberalnoj individui koja prirodno uživa građanske univerzalističke vrijednosti prava čovjeka...” (ibid.: 93-94). To znači da je noseća figura novog poretka 'subjekt prava' ('liberalna individua') u kojem je politički građanin, recimo to tako, apsorbirao buržuja (v. ibid.: 165). Tako se dokida 'interval' odnosno nesklad čovjeka (vlasnika) i građanina, koji je Marx raskrinkao. ${ }^{18}$ Kako je pojam kapitalizma jedan od simbola spomenutog raskoraka, za njega ideologijski gotovo da više nije bilo mjesta. ${ }^{19}$

Kuljić se potrudio da nas sustavno uvede u paradokse neoliberalnog svijeta. Primjerice, iako je sustav permanentno izložen kritici, uglavnom se pokazalo da ju je razmjerno dobro podnosio. Kuljić grupira te kritike, prvo, kao one koje sustav "napadaju' "iznutra sa stajališta njegovog mogućeg usavršavanja" (2018: 92). Ili, drugo, kao one koje igraju na nacionalizam, jer neoliberalizam osiromašuje donjoklasne sunarodnjake. Treći tip kritike, ukazujući na probleme srednje klase, zapostavlja radnike (v. ibid.). Ukratko, one su postavljene tako da kapitalizam kao takav ostaje legitiman projekt. Na rubovima neoliberalizma uspostavile su se i različite vrste razmjerno intelektualističkih kritika: "relativistička kritika kapitalizma... feministički rodni antikapitalizam... foucaultovski antikapitalizam u čijem je središtu biopolitika i razne desnoekstremističke... kritike globalizacije" (ibid.: 84). Postavlja se pitanje kako se sustav brani od svega navedenog i kako tretira vlastitu pogrešku budući da kritike sve češće vrlo konkretno ukazuju na "rast nejednakosti..., stalnu nesigurnost posla, prekarni status... ugroženost raznih manjina, razorni utjecaj kapitalizma na klimatske promjene i na ekologiju kulturnih uvjeta" (ibid.). Kuljić smatra da još uvijek važeći sustav ima odgovor: "kapitalizam proizvodi vjeru u sebe... na... način što nameće hegemoniju novom semantikom strateških pojmova" (ibid.).

Da bismo vidjeli je li to dovoljno, trebali bismo se osvrnuti na ukupnu logiku neoliberalizma odnosno tzv. postdemokracije. S tim u vezi Kuljić kaže da ova "podrazumijeva da je spor građana o dobrom i socijalno pravednom društvu okončan... treba samo jačati i usavršavati ustanove jer su ciljevi postignuti" (ibid.: 299). Može se reći da spomenuti sustav konsenzusa funkcionira ili je funkcionirao tako da pojavom 'greške' zapravo nije mogao biti posebno poremećen. Različiti oblici 'krivog' odnosno nepravde vodili su se samo kao razne vrste 'manjka' (npr.

18 Posrijedi je svojevrsna varijacija na Marxovo 'rodno biće' i njegovu metapolitiku. Vidi Rancière, 2015: 62-87; Žižek, 1999: 28-29.

19 Kuljić s pravom ukazuje na to da je pojam kapitalista zamijenjen investitorom. Investitora se prikazuje kao onog tko daje sve od sebe i tako "izlaže riziku vlastitu imovinu zbog općeg dobra" (2018: 92). 
posla ili identiteta), kako pokazuje Rancière u Nesuglasnosti (2015: 105). ${ }^{20}$ Iskazivanje 'krivog' prevodilo se tako u "identifikaciju, ili obradu manjka: objektivacija problema za koje treba znati koju državnu akciju zahtijevaju... koji su dijelovi društvenog tijela tu uključeni..." (ibid.: 97). U neoliberalizmu je onda nedvojbena "istovjetnost bolesti i zdravlja", što Rancièrea navodi da ustvrdi kako je "suzbijanje onog 'krivog'..., istovjetno njegovoj apsolutizaciji” (ibid.: 105). Stoga spomenute kritike ne potkopavaju neoliberalnu državu, nego upravo suprotno, pomažu joj da uvijek iznova nastupi s "društvenom medicinom ponovnog ulančavanja zajedničkog tkiva" (ibid.).

\section{Ljevica}

Sudbina ljevice je drugi istraživački interes autora koji je nalazi ugroženom "novim mnoštvom, raznolikošću i pluralizmom koji traže novu empatiju” (Kuljić, 2018: 121). Budući da to nije pretežit stav u teorijskoj literaturi, treba pokazati kako Kuljić shvaća pluralizam i demokraciju. Nema dvojbe da je posebno neraspoložen prema pluralizmu jer je ovaj, kako kaže, "daleko od demokracije" (ibid.: 122). Neprihvatljivost pluralizma za njega dijelom proizlazi iz kulture društvenih mreža koja stvara "naizgled demokratsku, a u stvarnosti kaotičnu političku javnost i novu maglu u kojoj se lakše manipulira" (ibid.). Sve se to zbiva u uvjetima nerijetke ekscesnosti i ispraznosti svijeta društvenih mreža i reality programa, što urušava suvremenu kulturu (v. ibid.: 255). Spomenuta je 'magla', po svemu, dio “cultural turna", odnosno šireg plana kojim "Bruxelles smišljeno neutralizira klasni antagonizam: kao test nameće gay parade i zaštitu vjerskih i nacionalnih manjina" (v. ibid.: 244). Značajnu ulogu u razrađenom sustavu legitimiranja današnjeg kapitalizma ima dakle "konstrukcija novih poredaka pripadanja i diferenciranja koji se manje ili više konstruiraju" (ibid.: 115). ${ }^{21}$ Dakle spomenuti obrat nije nastao nimalo spontano i njime su "društveno-ekonomske grupe - klase zamijenjene grupama s kulturnim identitetom" (ibid.: 244). Kuljić ovdje, ukazujući na "istinu iluzije" (Rancière, 2015: 81), postupa na metapolitički (ili, tradicionalnije rečeno, marksistički) način koji svakoj borbi “nameće svoju skrivenu 'političku' istinu klasne borbe za koju ova ne zna...” (ibid.). Različiti dionici takvih političkih (odnosno tzv. identitetskih) bor-

${ }^{20}$ U tom smislu Kuljić govori o 'neantagonističkoj socijalnoj isključenosti' (v. 2018: 23).

${ }^{21}$ Države nekadašnje Jugoslavije su, prema Kuljiću, bile jedan od poligona za promicanje tog postupka pa se zbilo npr. prebacivanje "od jugoslavenstva do hrvatstva, od marksizma ka pravoslavlju" (ibid.: 116). Položaj nacionalne države učvrstio se "u građanskom ratu na Balkanu 1990tih u kojem su etno-konfesionalni identiteti kao antiteza internacionalnom komunizmu ubrzali zaokret prema kapitalizmu" (ibid.). Stoga se Kuljiću nadaje da treba problematizirati upravo naciju kao "danas jedini samorazumljivi državni okvir koji se otima samorefleksiji i hegemonijski kontekst tumačenja svega" (ibid.). 
bi vjerojatno neće biti oduševljeni tom metodologijom, ali Kuljić na njoj inzistira, kao što to čine i tradicionalniji marksisti. ${ }^{22}$

Kuljićev stav o pluralizmu kao nekoj vrsti pitoresknog privida ponešto je platonistički, ${ }^{23}$ ali čini se da ovdje nije toliko stvar u pojavnosti (gay parade, Bruxelles, manjine...). Po svemu, iza toga nalazi se ideja o zajednici kao pluralitetu koji se ravna onim što Badiou u Metapolitici naziva 'zajednički smisao'. To je kriterij koji se pokazuje restriktivnim prema svima koji umjesto da uživaju 'slobodu mnijenja' vjeruju da zastupaju 'istinu' ${ }^{24}$ Budući da oni ugrožavaju 'zajednički smisao', tj. 'dobro', tumače se kao svojevrsno 'zlo' ("negativna volja sakaćenja zajedničkog ili zajednice”) i politika nema druge do "obznaniti negaciju ove negacije” (Badiou, 2005: 20). Kuljićevo neraspoloženje prema pluralizmu još je izraženije kad se vidi da je taj pojam zapravo drugo ime za "doktrinu konsenzusa koja je u biti vladajuća ideologija suvremenih parlamentarnih Država” (ibid.: 18).

Kad je posrijedi današnja demokracija, ona je za Kuljića također iluzorna. On ne dvoji da je tomu pridonijelo "neoliberalno reduciranje demokracije na sveopću permisivnost" (ibid.: 256). To je onda lažna demokracija, jer demokracije "nema tamo gdje su imovinske razlike velike" (ibid.: 255). Iz toga možemo iščitati razmjerno raširen stav među sociolozima, a to je da demokracija ne proizlazi iz sebe same, nego je povezana sa specifičnim tipom društva odnosno klase. Klasa je, dakako, ona srednja koja, čini se, treba biti na određenoj razini razvoja da bi uopće postojala demokracija. ${ }^{25}$ Demokracija je otud u normativnom smislu (razvijeno) građansko društvo, a u stvarnosti ljevica mora nastojati da ova ne bude svedena samo "na političku proceduru" (2018: 118). Tako više ne bi bila tek 'proceduralna borba' (ili 'površna mikropolitika'), nego i ekonomska demokracija ('dublja makropolitika'). 'Ekonomska demokracija' ovdje je zapravo eufemizam za ono što marksisti zovu klasnom borbom: "ekonomski interesi rada i kapitala... [tada su] neizmirljivi" (ibid.).

No umjesto klasne borbe suvremena ljevica posljednjih tridesetak godina, reklo bi se, tek ambijentira. Budući da nitko više ne može "ni zamisliti kako može

${ }^{22}$ U širem smislu slično E. M. Wood (1996), napose 8. i 9. poglavlje.

23 Platon smatra da 'demokratski čovjek' živi u 'uređenju' koje je “šareno odijelo, svim cvijećem išarano...” (2009: VIII, 557c). 'Demokratski čovjek' obično “veli da su sve naslade jednake i da ih treba jednako cijeniti” (ibid.: 561c).

${ }^{24}$ Badiou drži da se politika u (neo)liberalizmu pokazuje kao (javno) mnijenje, tj. "vježbe 'slobodnog rasuđivanja' u javnom prostoru u kojem na kraju krajeva vrijede isključivo mnijenja" (2005: 11).

25 Sa stajališta Marxa, ovdje bi trebalo biti oprezan, jer je za njega srednja klasa samo 'prijelazna klasa' koja "uobražava da uopće stoji iznad klasnog antagonizma” (Marx, 1979: 542). V. Pavićević i Simendić, 2016: 141-144. 
izgledati sistem koji nije kapitalistički”, prostor joj je izrazito sužen (ibid.: 88). Povrh toga, revolucionarno nasilje, njezin tradicionalni instrument, posve je izgubilo kredibilitet: "Do 1989. bilo je samorazumljivo i definirano na prirodnopravni način kao otimanje otetog..." (ibid.). Što onda ljevica treba i može učiniti? Kako bi uopće imala smisla, za početak se, po Kuljiću, treba ideološki odnosno idejno osvijestiti. $\mathrm{S}$ tim u vezi prvo mora zaboraviti 'bespomoćni antikapitalizam' odnosno moralističku kritiku kapitalizma (v. ibid.: 87). Ta vrsta kritike nije zbiljski antikapitalizam, nego isključivo "upozorava na pomanjkanje njegove održivosti' (ibid.: 88). Shodno tome, za Kuljića antikapitalizam ostaje "prazna i višesmislena metafora" (ibid.: 89).

Nadalje Kuljić, tragom Marcusea, kaže da treba iznaći revolucionarni subjekt koji ima 'životnu potrebu' za revolucionarnom situacijom. Tu je znakovit njegov stav da "revolucije nema i otud što nema filozofske osmišljenosti novog gnjeva kao što je to bilo prosvjetiteljstvo 1789., ili marksizam 1917." (ibid.: 259). ${ }^{26}$ Promicanje filozofije u odnosu na politiku traži barem letimičan prikaz odnosa filozofije, ili teorije, i politike kod nekih drugih suvremenih lijevih mislilaca. Primjerice, Sylvain Lazarus u Antropologiji imena ne podupire taj stav, jer ako npr. filozofiji dajemo prednost, onda politiku mislimo kao "objekt ili kažemo da je ona objekt mišljenja, [a] to znači ponovo zapasti u klasizam, ili etatizam ili u znanost i ne promišljati politiku njom samom" (Lazarus, 2013: 35). Politika u Lazarusovu shvaćanju treba dakle izbjeći biti izvanjski 'konstituirani objekt', odnosno treba ju "promišljati $\mathrm{u}$ interiornosti, tako da ona nikad ne postane objekt" (ibid.). Alain Badiou uglavnom dijeli tu poziciju pledirajući da se "filozofski nadovezuje na politiku samo pod uvjetom politike" (Badiou, 2005: 55). ${ }^{27}$ Iz toga je razvidno da Kuljić politiku vidi primarno kao objekt znanosti, neke varijante filozofije, odnosno marksističke teorije.

Kad je riječ o statusu nasilja, Kuljić kaže da svaka represija od strane postojećeg ('neumnosti') čini uporabu revolucionarne sile legitimnom (2018: 241). Pozovemo li se na Marcuseovu Represivnu toleranciju, nalazimo da je nasilje 'potlačenih klasa' legitimno, odnosno da je donijelo 'napredak civilizacije', a to se ne može reći za nasilje 'vladajuće klase' (Marcuse, 1983: 97). Kako je u kapitalističkim društvima prevladala 'lažna svijest', Marcuse smatra da nema više smisla podupirati 'demokratsku toleranciju' jer je represivna: "Potlačene skupine imaju 'prirodno pravo' na otpor, pravo da posegnu i za nezakonitim sredstvima - ako se pokaže da su zakonita nedovoljna" (ibid.: 103).

${ }^{26}$ Ili još: "Bez teorijskog osmišljavanja vizije budućeg” neće se dogoditi revolucija, nego "bune zarobljene u vulgarnom antiteorijskom realizmu" (2018: 260).

27 Za Badioua filozofija ne može a da ne 'misli politiku', jer je to “imanentan način njezinog podvrgavanja uvjetu realnih politika" (2005: 54). 
Treba reći da je Represivna tolerancija uporabljiva i za druge potrebe Kuljićeva projekta, čime se zbila stanovita rehabilitacija Marcuseova stava o toleranciji. ${ }^{28}$ Primjerice, može dijelom dati odgovor na stalno Kuljićevo pitanje o revoluciji i uvjetima za njezino ostvarenje. Prvi se tiče postojanja (klasnog) subjekta promjene, drugi se odnosi na "jasnu klasnu svijest i političku organizaciju", a treći na to da subjekt nije previše unutar sustava kapitalizma (Kuljić, 2018: 242). Iako se subjekt revolucije prema Marcuseu ne može ustanoviti prema klasnom položaju, moguće je nešto pomaknuti i na tom planu ako se u društvu "stvori duhovni prostor za negaciju i refleksiju" (Marcuse, 1983: 100). Treba dodati da je Marcuseov projekt 'apstraktan' u odnosu na postojeće 'administrativno društvo': “on se svodi na... oslobađanje jezika od tiranije orvelovske sintakse i logike, na stvaranje pojmova kojima se spoznaje zbilja... [pa] više nego ikad vrijedi tvrdnja da napredak slobode zahtijeva napredak svijesti o slobodi" (ibid.). To otprilike odgovara onomu što Kuljić naziva 'semantičkom subverzijom' neoliberalizma, ili ‘pojmovnom osvježavanju antikapitalizma' (2018: 122). Kao 'subjekti' mogu se pojaviti mladi ljudi koji su izloženi kritičkim uvidima, tj. 'protuobrazovanju' izvan sustava što bi funkcioniralo kao "radikalna kritika, duhovni prevrat” (Marcuse, 1983: 101).

Neovisno o prijeporima glede Marcuseove ideje o društvu autonomnih pojedinaca, ${ }^{29}$ nije teško pokazati da njegova 'oslobađajuća tolerancija' danas ima nemali politički učinak. Različite vrste 'događajne nadodređenosti' (Badiou) kao što je, primjerice, ubojstvo Georgea Floyda od strane policije, odnosno pokret Black Lives Matter, predstavljaju "borbu protiv ideje tolerancije koja zapravo, pospješuje i podupire očuvanje sadašnjeg stanja nejednakosti i diskriminacije" (ibid.: 109). Kako svjedočimo, 'radikalna manjina', koja je ustala protiv policijskog nasilja, drži da može promijeniti 'nečovječnu realnost' (Marcuse) jer se "ne pokorava pravilima ponašanja što toleriraju destrukciju i represiju” (ibid.). U tom slučaju 'oslobađajuće tolerancije' isto tako nalazimo odbacivanje "apologetskih diskursa o liberalnom kapitalizmu”, što nas zasad najviše približava onomu što Kuljić zaziva

${ }^{28}$ Svojedobno je politolog Ivan Prpić kritizirao Marcusea. Prpić je u okviru povijesnog poraza socijalističkih zemalja konstatirao da su Marcuseove ideje neprikladne i kontraproduktivne: "Slom poredaka koji su institucionalizirali represiju u ime apsolutnog i istinitog znanja povijesnih zakonitosti još je jednom pokazao da redukcija tolerancije na istinite iskaze nužno ukida ne samo slobodu nego i povijesni napredak" (Prpić, 1990: 22).

${ }^{29}$ Marcuse ne drži da je razlikovanje demokracije i diktature ključno za ideju tolerancije, barem kako ju on vidi: "Jedina prava alternativa... bila bi društvo u kojem bi se 'narod' pretvorio u autonomne pojedince oslobođene opresivnih zahtjeva borbe za održanjem u interesu dominacije..." (Marcuse, 1983: 95). Kako takvo društvo 'još ne postoji nigdje', onda se otvaraju pitanja "tko može i na temelju kojih kriterija definirati političke razlike između istinitog i lažnog...?” (ibid.). Kritičari ukazuju na problematične implikacije svojevrsne osamostaljenosti takve ideje (tolerancije) u odnosu na bilo koje konkretno društvo (v. Prpić, 1983: 20-21). 
kao "pripremu i ostvarenje one mogućnosti koja je nemoguća sa stajališta postojećeg" (2018: 95, 241).

Svi su, međutim, izgledi da je Kuljić u tumačenju revolucije i onoga što joj se ispriječilo skloniji nešto izvornijem klasizmu. ${ }^{30}$ Stoga je Gramsci dobio svoje mjesto u njegovu istraživanju. Gramsci je, baveći se sličnim pitanjem, uočio da je jako građansko/civilno društvo osnovna prepreka revoluciji. Dakako, danas ne treba zanemariti ni druge uzroke od (globalizirane) ekonomije i (neoliberalne) države do 'nacionalizmom rascjepkane radničke klase', što čini "autentičnu antirevolucionarnu situaciju” (ibid.: 242). Ipak, u Prognanim pojmovima hegemonija, kako ju vidi Gramsci, ima prednost pred ostalim uzrocima spomenute situacije. Tako je klasa hegemonijska kad se većina, na neki način, pronalazi u njenim interesima, što njezinu vladavinu čini "mješavinom suglasnosti i prinude" (v. ibid.: 256). Iako danas postoji određena kritika kapitalizma, daleko je manje prisutna "svijest o načinu njegova dokidanja" (ibid.: 241-242). To proizlazi iz činjenice da "svijest o uzrocima ovog stanja zamagljuju pojmovi vladajućih" (ibid.: 242).

Po svemu, Kuljić vjeruje da je (neoliberalna) hegemonija još uvijek učinkovita. O tome se može itekako raspravljati, i to upravo na osnovi čitanja Gramscija. Primjerice, Gramsci nalazi da je hegemonija u krizi (što je npr. slučaj nakon tzv. Velike recesije 2008.) zato "što je vladajuća klasa promašila u kakvom svom velikom političkom pothvatu... ili zato što su široke mase... odjednom prešle iz političke pasivnosti u određenu aktivnost i postavljaju zahtjeve koji u svojoj neorganskoj složenosti čine revoluciju" (Gramsci, 1979: 138). Postavlja se, dakako, pitanje zašto se još ne ostvaruje revolucija, a ima tzv. "blokada raznih prostora", koje su za Kuljića "surogat neproceduralnog osvajanja vlasti", nikako "virusi širokog masovnog ustanka” (2018: 245-246). Po mom sudu, 'blokade', iako nisu tradicionalno shvaćene revolucije, jasan su znak slabljenja hegemonije jer su građani politički radikalniji, pa bilo to i kroz redefiniranje prostora.

Također treba reći da Gramsci zapravo nudi odgovor na pitanje o izostanku revolucije $u$ krizi hegemonije, $i$ to na temelju njegova pojma pasivne revolucije. Ta revolucija predstavlja pojavu u kojoj "sama teza u stvarnosti razvija sve svoje borbene mogućnosti sve dok ne pokupuje tobožnje predstavnike antiteze" (Gramsci, 1979: 169). Ukratko, vladajuće klase različitim taktikama nastoje onemogućiti snage koje u 'organskoj krizi' (Gramsci) pokazuju revolucionarna stremljenja. Sve u svemu, 'pasivna revolucija' predstavlja jednu od turbulentnijih faza na razvojnom putu kapitalizma, a ovu kojoj svjedočimo u posljednjih desetak godina društvene

30 Pojam socijalne revolucije je, dakako, u okruženju neoliberalizma "izgubio svoju pozitivnu konotaciju", ali je zato diskurzivno-političkim operacijama "širi pojam revolucije postao formalan i inflatoran: govori se o Islamskoj revoluciji, revoluciji odozgo, Plišanoj i Narančastoj revoluciji” (Kuljić, 2018: 225). 
znanosti zborno nazivaju populizmom. U osnovi, na djelu je razmjeran uspjeh vladajućih klasa u zahtjevnoj preobrazbi kapitalizma. ${ }^{31} \mathrm{~S}$ druge strane, treba naglasiti da se niže klase muče glede "elaboriranja vlastitih hegemonijskih aparata... koji bi se mogli oduprijeti apsorpcijskoj logici pasivne revolucije" (Thomas, 2009: 157).

Iako zna da je kapitalizam daleko od stare slave, Kuljić smatra da je to još uvijek "moćni organizirani klasni protivnik" (2018: 236). To ne mora biti sporno, ali pozovemo li se na Gramscija, važnije je da se pitamo je li neoliberalizam još uvijek 'vodeći' ili je tek 'vladajući'. Naime, Gramsci kaže: “Ako je vladajuća klasa izgubila svoj konsenzus, nije više vodeća, nego je samo vladajuća... to prije svega znači da su se mase odvojile od svojih tradicionalnih ideologija i da se više ne vezuju za ono u što su tradicionalno vjerovale" (Gramsci, 1971: 275-276). Pritom treba računati da "staro umire, a novo se ne može roditi i u tom se interregnumu pojavljuje velik raspon morbidnih simptoma" (ibid.: 276). Gramsci ipak tu ne isključuje stvaranje 'nove kulture' (ibid.), tj. hegemonije, ali to je jako neizvjesno. Po svemu, Kuljić je još manje optimističan od Gramscija, što zna graničiti s defetizmom ${ }^{32}$ jer svako eventualno socijalno popuštanje suvremenog kapitalizma vidi kao "mjeru [koja] nije obvezujuća" (Kuljić, 2018: 355). Neovisno o izgledima za naprednu hegemoniju, ipak treba reći da je ona neoliberalna završila (prema Gramscijevim, a vjerojatno i drugim kriterijima). Što će biti dalje, čini se, nije na društvenim odnosno humanističkim znanostima. Politika će, naime, to odrediti sama i "treba je promišljati počevši od nje same, a ne pomoću drugih disciplina” (Lazarus, 2013: 35).

I na kraju, trebamo li posegnuti za Prognanim pojmovima? U pregledu Kuljićevih ideja vodio sam se onim što politološki nalazim najzanimljivijim, ali sam za to, vjerujem, našao uporište u njegovu opredjeljenju da nam pruži, staromodno rečeno, angažirani 'normativno-politički osvrt'. Iznesene se ocjene temelje na stavu da se o svemu tome može, kako sam već napisao, 'itekako raspravljati', što ne dovodi u pitanje ukupnu vrijednost knjige. Dakle, neovisno o svemu prethodno izrečenom, Prognani pojmovi vrijedan su primjer istraživanja političke i spoznajne logike pojmova. Usto su jedan od rijetkih promišljeno prohodnih pregleda Koselleckovih viđenja pojmovne povijesti. U tom bi smislu ova knjiga mogla biti poticajem za podizanje metodologijske razine koja, barem što se tiče političkih pojmova, često ne ide dalje od tek formalnog inzistiranja na njihovoj važnosti. Kuljić ovom knjigom želi raskinuti s takvom praksom i to uspješno ostvaruje postupkom 'kontrastnih pojmovnih parova'. To je dovoljno da se bez oklijevanja posegne za njom.

31 Iscrpno viđenje inačica 'pasivne revolucije' u Seymour, 2013.

${ }^{32}$ Gramsci je kritičan prema takvom raspoloženju; v. Thomas, 2009: 156, f. 59. 


\section{LITERATURA}

Badiou, Alain. 2005. Metapolitics. Verso. New York.

Foucault, Michel. 2016. Rođenje biopolitike. Sandorf Mizantrop. Zagreb.

Gramsci, Antonio. 1971. Selections from the Prison Notebooks (ur. i prev. Quentin Hoare i Geoffrey Nowell Smith). International Publishers. New York.

Gramsci, Antonio. 1979. O državi (ur. I. Petrinović). Radničke novine. Beograd.

Koselleck, Reinhart. 2004. Future Past: On the Semantics of Historical Time. Columbia University Press. New York.

Laclau, Ernesto. 2005. On Populist Reason. Verso. New York.

Lazarus, Sylvain. 2013. Antropologija imena. Grupa za konceptualnu politiku \& kuda. org. Novi Sad.

Marcuse, Herbert. 1983. Represivna tolerancija, u: Prpić, Ivan (ur.): Kritika čiste tolerancije. Biblioteka 11. teza. Zagreb: 79-104.

Marcuse, Herbert. 1989. Čovjek jedne dimenzije. Veselin Masleša. Sarajevo.

Marx, Karl, 1979. 18 Brumaire Louisa Bonapartea, u: Dragičević, Adolf / Mikecin, Vjekoslav / Nikić, Miomir (ur.): Glavni radovi Marxa i Engelsa. Stvarnost. Zagreb: 517-587.

Noys, Benjamin. 2010. The Grammar of Neoliberalism, www.academia.edu, pristupljeno 25. 7. 2020.

Pavićević, Đorđe i Simendić Marko. 2016. Disciplinovanje demokratije: klasične kritike i moderna sporenja. Fabrika knjiga. Beograd.

Platon. 2009. Država. Naklada Jurčić. Zagreb.

Prpić, Ivan. 1983. Protuslovlja tolerancije, u: Prpić, Ivan (ur.): Kritika čiste tolerancije. Biblioteka 11. teza. Zagreb: 7-22.

Prpić, Ivan. 1990. Tolerancija, u: Prpić, Ivan / Puhovski, Žarko / Uzelac, Maja (ur.): Leksikon temeljnih političkih pojmova. Školska knjiga. Zagreb: 19-22.

Rancière, Jacques. 2012. Na rubovima političkog. Fedon. Beograd.

Rancière, Jacques. 2015/1995. Nesuglasnost: politika i filozofija. Biblioteka Politička misao. Zagreb.

Seymour, Richard. 2013. Notes on passive revolution, http://www.leninology. co.uk/2012/07/notes-on-passive-revolution.html, pristupljeno 18. 8. 2020.

Thomas, Peter D. 2009. The Gramscian Moment: Philosophy, Hegemony and Marxism. Brill. Leiden/Boston.

Wood, Ellen M. 1996. Democracy against Capitalism. Oxford University Press. London. 
Žižek, Slavoj. 1994. Introduction: The Spectre of Ideology, u: Žižek, Slavoj (ur.): Mapping Ideology. Verso. New York: 1-33.

Žižek, Slavoj. 1999. Carl Schmitt in the Age of Post-politics, u: Mouffe, Chantal (ur.): The Challenge of Carl Schmitt. Verso. New York: 18-37.

Tonči Kursar je izvanredni profesor političke teorije na Fakultetu političkih znanosti Sveučilišta u Zagrebu.

Kontakt: Tonči Kursar, Fakultet političkih znanosti, Lepušićeva 6, 10000 Zagreb. E-mail: tonci.kursar@fpzg.hr 